\title{
Status of Biodiversity at Wetland Ecosystem of Mohangonj Upazila in Netrakona District
}

\author{
Mohammad Zahangeer Alam \\ Department of Bioenvironmental Science, Bangabandhu Sheikh Mujibur Rahman Agricultural University (BSMRAU), \\ Gazipur 1706, Bangladesh
}

Correspondence should be addressed to Mohammad Zahangeer Alam; mohammad.alam@email.wsu.edu

Received 19 June 2014; Revised 9 August 2014; Accepted 21 August 2014; Published 2 September 2014

Academic Editor: Dafeng Hui

Copyright (C) 2014 Mohammad Zahangeer Alam. This is an open access article distributed under the Creative Commons Attribution License, which permits unrestricted use, distribution, and reproduction in any medium, provided the original work is properly cited.

\begin{abstract}
Species in wetlands provide ecosystem services, and protect the sustainable environment for human beings. The wetland biodiversity has been impacted at Mohangonj in Bangladesh due to the development of major environmental threats. The present research is undertaken to report the species status, wetland properties, and major environmental pressures in each wetland ecosystem. Among the recorded species, the total percentage of visible, threatened, endangered, and extinct species was $69.23,18.62,10$, and $1.92 \%$ in these wetland ecosystems, respectively. The highest number of threatened species was found in the wetland of Aizda (29\%); the lowest was in Khalaura (8\%). The maximum number of endangered species was noted in the wetland of Sonarthal (16\%), and the minimum was in Chadra (4\%) wetland. Four percent species were in the extinct category at some of the wetland ecosystems. Wetland biodiversity protects wetland ecosystem services and the sustainable environment for species conservation. Continuous monitoring of wetland biodiversity might be helpful for the conservation of species in the wetland ecosystem.
\end{abstract}

\section{Introduction}

Wetlands are one of the world's key natural resources. It is the transition between land and water and are the most productive ecosystems in the world. Wetlands can be natural or artificial such as marsh, fen, and peat land; wetland's water may be permanent or temporary, static or flowing, and fresh or brackish, including the areas of marine water, the depth of which at low tide does not exceed six meters [1]. The biodiversity of the wetland ecosystem is variable in the world; it encompasses the range of living things, the degree of genetic variation, and the wealth of different habitats within a particular ecosystem. The wetland habitat is distinct from any other land-based terrestrial habitats, and the organisms of this ecosystem face specific environmental problems. However, most of these problems are overcome through the development of a plant or animal's distinctive behavior. These wetland species are visible in different climatic regions due to their typical characteristics in various parts of the world; they are not confined to certain areas or particular zones of latitude as are most of the great global biomes, such as rain forest, savanna, and desert area. As a consequence, wetlands are a great source of global biodiversity within the major climatic belts due to the evolved collection of animals and plants.

Although some species are able to overcome environmental threats, wetland species are still vulnerable in the world. The reduction of species is a common phenomenon in the wetland and terrestrial ecosystem. Since the year 1600, some animal species disappeared due to the introduction of alien species, habitat destruction, hunting or deliberate execution, human population growth, unsustainable patterns of consumption, increasing production of waste, urban development, and international conflicts [2, 3]. 150 animal species are isolated from wetland habitats, and 33 are at risk in their habitats; 125 species are critically endangered; 220 are vulnerable; and 98 are threatened in wetland ecosystems [4]. In Florida's wetland ecosystem (USA), 131 species are state red listed, 67 are federally endangered species, and 835 species are considered rare [5]. Similarly, the Hakaluki wetland at 
Sylhet in Bangladesh faces species scarcity. It contains more than 238 interconnecting wetlands, but most of the species are rare, endangered, threatened, and vulnerable in this wetland ecosystem [6-8]. As a consequence, the relationship between wetland biodiversity, ecosystem services, and human benefits received much more attention for the protection of the wetland biodiversity [9-11].

Bangladesh is rich in wetland biodiversity with 280 fresh water and 490 marine species available at different wetland ecosystems [12]. These wetlands provide natural ecosystem services such as water, fish, edible animals, wood, energy, and recreational activities [13-15]. However, wetland species and ecosystem service vulnerability are elevated in Bangladesh due to the agriculture land conversion, forest clearing, climate change, harvesting of natural resources, and the introduction of alien species [16] that lead to the deterioration of wetland resources. The depletion of the wetland resource also depends on the wetland type and ecosystem services, as they are valuable to human beings [17]. For this reason, substantial investments are needed to systematically inventory wetland resources for full documentation $[18,19]$. Therefore, the documentation of species status in the Mohangonj wetland might be helpful for the protection of wetland ecosystems which leads to the defense of biological diversity and sustainable environment.

\section{Materials and Method}

2.1. Description of Study Area. Wetland species diversity was recorded at Mohangonj upazila in Netrokona district in Bangladesh from January to December in 2013. The selected wetlands were Nagadura, Dingaputa, Chadra, Sonapeti, Aizda, Firail, Nader, Sonarthal, and Khalaura. The geographical location of the Mohangonj upazila (Netrokona district) is an area of $243.20 \mathrm{sq} \mathrm{km}$; it is bounded by Barhatta and Dharmapasha upazilas on the north, Madan and Khaliajuri upazilas on the south, Jamalganj and Khaliajuri upazilas on the east, and Atpara upazila on the west. The geographic coordinates of Mohangonj upazila are $24^{\circ} 52^{\prime} 21^{\prime \prime} \mathrm{N}$ $90^{\circ} 58^{\prime} 32^{\prime \prime} \mathrm{E}$ degrees. The sites of the study are illustrated in Figure 1. Photographic scenarios of wetlands are highlighted in Figure 2.

2.2. Data Collection. The status of wetland species, properties of the different wetlands, and the environmental threats were documented from the study areas with the help of lab research assistants. Information was collected through interviews with approximately 10 people who live in the study area. The properties of wetland ecosystem such as wetland area, water life, topography, type of wetland, major crops, and use of water were recorded in Table 1. Tables 2 and 3 highlight information regarding the status of visible, threatened, endangered, and extinct species. Major environmental threats and their impacts on wetland biodiversity, ecosystem service, and sustainable environment were noted (Figure 3 ). The percent of visible, threatened, endangered, and extinct species was analyzed based on the total number of recorded

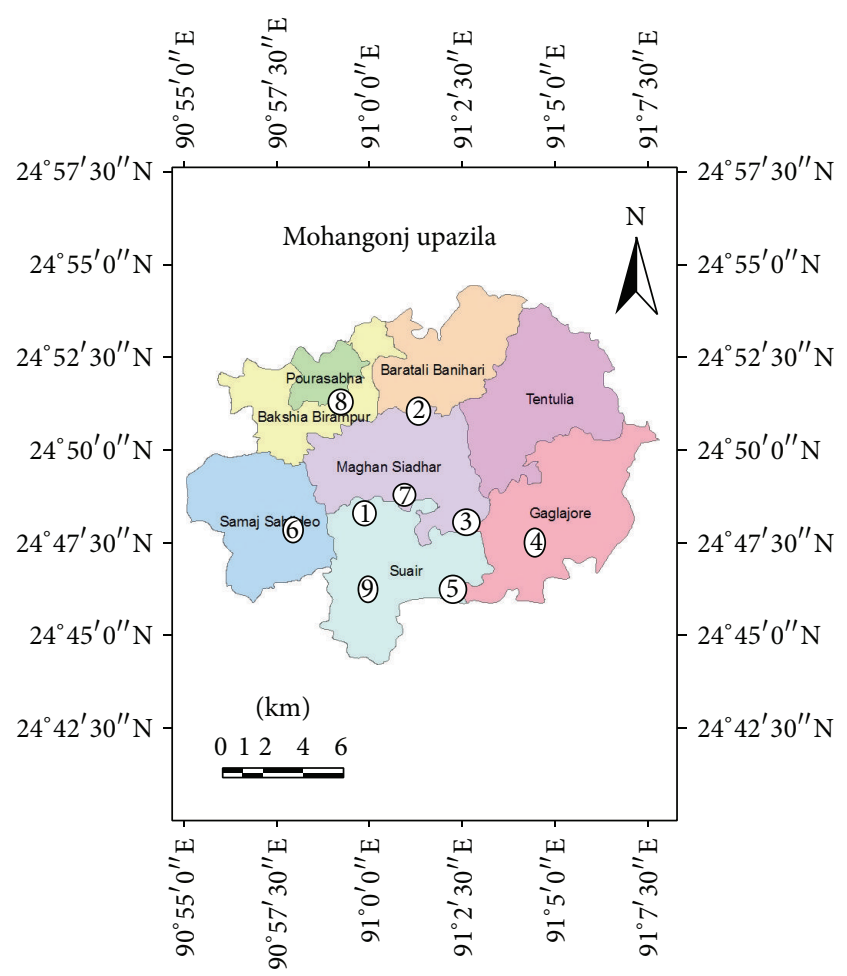
(1) Nagadura
(6) Firail
(2) Dingaputa
(7) Nader
(3) Chadra
(4) Sonapeti
(8) Sonarthal
(5) Aizda
(9) Khalaura

FIGURE 1: Sites of study area on the different wetlands biodiversity.

fish, aquatic plant, and bird species at different wetland ecosystems which are highlighted in Table 3 and Figure 4.

\section{Results}

3.1. Properties of Wetland Ecosystem. All wetlands are natural in the study areas. Wetland sizes were variable in both the dry and rainy seasons. The wetland size of Nagadura, Dingaputa, Chadra, Sonapeti, Aizda, Firail, Nader, Sonarthal, and Khalaura was 50, 115200, 200, 120, 100, 120, 200, 120, and 125 acres, respectively, during the rainy season. Among all the wetlands, the smallest wetland was Nagadura at 50 acres, and Sonapeti, Aizda, Sonarthal, Firail, and Khalaura were similar in size during the rainy season. The ranges of the wetland areas were 5 to 20000 acres in the dry season. Some of the wetlands were similar in size during the dry season such as Sonapeti, Firail, Nader, and Khalaura. Rainfall is the main source of water for all wetlands. Water life was variable in the different wetlands; also topography of the wetlands was flat to medium high. Generally, water is used for irrigation purposes in rice fields, the major crop in Bangladesh (Table 1).

3.2. Major Threats for Wetland Ecosystem Service and Biodiversity. Major environmental threats were recorded in the different wetland ecosystems such as intensive agricultural 

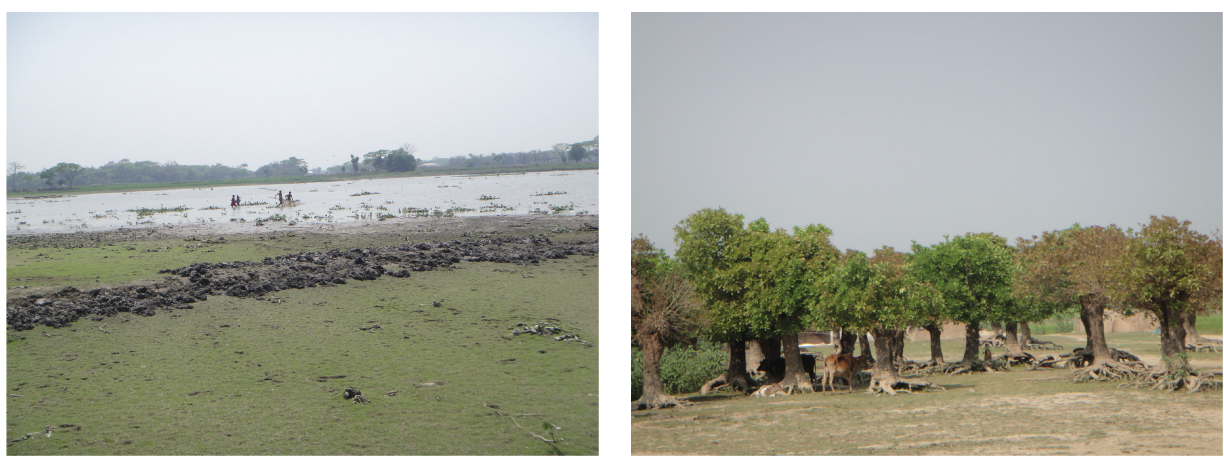

FIGURE 2: Photographic scenario of the status of wetland ecosystem in the dry season.

TABLE 1: The properties of the different wetland ecosystems at Mohangonj upazila in Netrokona district.

\begin{tabular}{lccccccccc}
\hline Sl. number & $\begin{array}{c}\text { Name of } \\
\text { wetland }\end{array}$ & $\begin{array}{c}\text { Area in rainy } \\
\text { season (acre) }\end{array}$ & $\begin{array}{c}\text { Area in dry } \\
\text { period (acre) }\end{array}$ & $\begin{array}{c}\text { Source of } \\
\text { water }\end{array}$ & Water life & $\begin{array}{c}\text { Topography of } \\
\text { surrounding area }\end{array}$ & $\begin{array}{c}\text { Major } \\
\text { crops }\end{array}$ & $\begin{array}{c}\text { Use of } \\
\text { water }\end{array}$ & $\begin{array}{c}\text { Type of } \\
\text { wetland }\end{array}$ \\
\hline 1 & Nagadura & 50 & 10 & Rainfall & Medium & Flat & Rice & Irrigation & Natural \\
2 & Dingaputa & 115200 & 20000 & Rainfall & High & Flat & Rice & Irrigation & Natural \\
3 & Chadra & 200 & 80 & Rainfall & Medium & Medium high & Rice & Irrigation & Natural \\
4 & Sonapeti & 120 & 50 & Rainfall & Medium & Medium high & Rice & Irrigation & Natural \\
5 & Aizda & 100 & 5 & Rainfall & Low & Medium high & Rice & Irrigation & Natural \\
6 & Firail & 120 & 50 & Rainfall & Medium & Medium high & Rice & Irrigation & Natural \\
7 & Nader & 200 & 50 & Rainfall & Medium & Medium high & Rice & Irrigation Natural \\
8 & Sonarthal & 120 & 50 & Rainfall & Medium & Medium high & Rice & Irrigation & Natural \\
9 & Khalaura & 125 & 40 & Rainfall & Low & Medium high & Rice & Irrigation Natural \\
\hline
\end{tabular}

crop cultivation, residential and commercial area development, invasive alien species, pollution, hunting, climate change, change in fire regime, dams/water management, intensive fish culture, human disturbance, transport/service corridors, and the intensive use of pesticides. These threats are constraints for wetland biodiversity, ecosystem services, and sustainable livelihood (Figure 3).

3.3. Visible Species. Twenty fishes (20), 4 aquatic plants, and 7 bird species were recorded in the different wetland ecosystems. The percent of visible species of Nagadura, Dingaputa, Chadra, Sonapeti, Aizda, Firail, Nader, Sonarthal, and Khalaura wetland was $61.90,66.75,72,72,62.5,70,72$, 71 , and $75 \%$, respectively. Most of the wetland showed similar percentage of the species visibility. The total species visibility was $69.23 \%$ in all wetland ecosystems (Table 3 and Figure 4 ). The visible fish species that were recorded at different wetland ecosystems include Macrognathus pancalus, Puntius puntio, Het eropneustes fossilis, Clarias batrachus, Labeo rohita, Anabas testudineus, Mystus vittatus, Glossogobius giuris, Lepidocephalichthys guntea, Penaeus monodon, Gibelion catla, Channa punctata, Chanda nama, Salmostoma phulo, Amblypharyngodon mola, and Corica soborna. Similarly, visible aquatic plant species were documented, for instance, Eichhornia crassipes, Pistia stratiotes, Nymphaea nouchali, and Nymphaea lotus at different wetland ecosystems (Table 2).

3.4. Threatened Species. The percent of threatened species (fish, aquatic plant, and birds) were 28, 23, 20, 13.63, 29,
$21,12,13$, and $8 \%$ in the wetlands of Nagadura, Dingaputa, Chadra, Sonapeti, Aizda, Firail, Nader, Sonarthal, and Khalaura, respectively. A total of $18.62 \%$ of species were threatened in these wetland ecosystems (Table 3 ). The threatened species were Boal (Wallago attu), Balihash (Anas platyrhynchos), Bog (Ardeola grayii), Gangchil (Larus ridibundus), Machranga (Alcedo atthis), and Pankouri (Phalacrocorax fuscicollis) (Table 2). The highest percent of the threatened species was recorded in the wetland of Aizda; the lowest was in the Khalaura wetland, and similar numbers of the threatened species were found in the wetlands of Dingaputa, Chadra, and Firail (Table 3 and Figure 4).

3.5. Endangered Species. The percent of endangered species was $9.52,10,4,9,8,9,12,16$, and $12.5 \%$ in the wetlands of Nagadura, Dingaputa, Chadra, Sonapeti, Aizda, Firail, Nader, Sonarthal, and Khalaura, individually. Among these records, species of Pabda (Ompok pabda), Chital (Chitala chitala), Ilish (Tenualosa ilisha), and Kalim bird(Porphyrio porphyrio) were found to be endangered species (Table 2). The highest percent of the endangered species was found in the wetland of Sonarthal (16\%); the lowest was in the Chadra (4\%) wetland. A total of $10 \%$ of species were endangered in these wetland ecosystems (Table 3 and Figure 4).

3.6. Extinct Species. Four percent of the extinct species were found in the wetlands of Nagadura, Sonapeti, Nader, and Khalaura (Table 3 and Figure 4). The species of Shukun (Gyps 
TABLE 2: Recorded of the fish, aquatic plant and birds species at different wetland ecosystems.

\begin{tabular}{|c|c|c|c|}
\hline Name of species & Local name & English name & Scientific name \\
\hline \multirow{20}{*}{ Fish } & Chikra (Guchi) & Barred Spiny Eel & Macrognathus pancalus \\
\hline & Puti & Puntio Barb & Puntius puntio \\
\hline & Shing & Stinging Catfish & Heteropneustes fossilis \\
\hline & Magur & Walking Catfish & Clarias batrachus \\
\hline & Boal $^{*}$ & Freshwater Shark & Wallago attu \\
\hline & Rui & Rohu & Labeo rohita \\
\hline & Koi & Climbing perch & Anabas testudineus \\
\hline & Pabda** & Pabdah catfish & Ompok pabda \\
\hline & Tengra & Striped Dwarf Catfish & Mystus vittatus \\
\hline & Bailla & Tank goby & Glossogobius giuris \\
\hline & Gutum & Guntea loach & Lepidocephalichthys guntea \\
\hline & Chingri & Shrimp & Fenneropenaeus indicus/Penaeus monodon \\
\hline & Katal & Catla & Gibelion catla \\
\hline & Taki & Spotted Snakehead & Channa punctate \\
\hline & Chital $^{* *}$ & Clown Knifefish & Chitala chitala \\
\hline & Chada (Chanda) & Elongate Glass Perchlet & Chanda nama \\
\hline & Chela & Fine-scale razor belly minnow & Salmostoma phulo \\
\hline & Mola & Mola carplet & Amblypharyngodon mola \\
\hline & Ilish $^{* *}$ & Hilsa shad & Tenualosa ilisha \\
\hline & Kachki & Ganges river sprat & Corica soborna \\
\hline \multirow{4}{*}{ Aquatic plant } & Kachuripana & Common water hyacinth & Eichhornia crassipes \\
\hline & Topapana & Water cabbage/water lettuce/Nile cabbage/shellflower & Pistia stratiotes \\
\hline & Shapla & Red and blue water lily & Nymphaea nouchali \\
\hline & Padma & white lotus or sacred lotus & Nymphaea lotus \\
\hline \multirow{7}{*}{ Bird } & Bali Hash* $^{*}$ & Wild Mallard or Wild Duck & Anas platyrhynchos \\
\hline & Bog* & Indian Pond Heron or Paddybird & Ardeola grayii \\
\hline & Shukun ${ }^{* * *}$ & Bengal Vulture & Gyps bengalensis \\
\hline & Machranga* $^{*}$ & Common Kingfisher & Alcedo atthis \\
\hline & Pankouri $^{*}$ & Indian Cormorant or Indian Shag & Phalacrocorax fuscicollis \\
\hline & Kalim Bird ${ }^{* *}$ & Purple Moorhen or Purple Swamphen & Porphyrio porphyria \\
\hline & Gangchil $^{*}$ & Black Headed Gull & Larus ridibundus \\
\hline
\end{tabular}

* indicated threatened species.

$* *$ indicated endangered species.

$* * *$ indicated extinct species.

TABLE 3: Status of species (fish, aquatic plant, and bird species) at different wetland ecosystems of Mohangonj upazila in Netrokona district.

\begin{tabular}{lcccc}
\hline $\begin{array}{l}\text { Name of } \\
\text { wetland }\end{array}$ & Visible \% & $\begin{array}{c}\text { Threatened } \\
\%\end{array}$ & Endangered \% & Extinct \% \\
\hline Nagadura & 61.90 & 28 & 9.52 & 4.76 \\
Dingaputa & 66.75 & 23 & 10 & 0 \\
Chadra & 72 & 20 & 4 & 0 \\
Sonapeti & 72 & 13.63 & 9 & 4.54 \\
Aizda & 62.5 & 29 & 8 & 0 \\
Firail & 70 & 21 & 9 & 0 \\
Nader & 72 & 12 & 12 & 4 \\
Sonarthal & 71 & 13 & 16 & 0 \\
Khalaura & 75 & 8 & 12.5 & 4 \\
\hline Total & $69.23 \%$ & $18.62 \%$ & $10 \%$ & $1.92 \%$ \\
\hline
\end{tabular}

The percent of visible, threatened, endangered, and extinct species was found based on the total recorded fish, aquatic plant, and bird species.

bengalensis) was identified as an extinct. A total of $1.92 \%$ of species were extinct in these wetland ecosystems (Table 2).

\section{Discussion}

Wetland biodiversity is the key natural resource for maintaining sustainable environment. It protects many species for a long period of time and maintains friendly interaction among different species in their ecosystems. Wetland species interaction at Mohangonj upazila in Bangladesh has deteriorated in the form of species vulnerability even though it has a diverse geology, a large river network, and few big lakes. Many of these wetlands have already lost their biodiversity and ecosystem services because of intensive agriculture and aquaculture, logging, development of residential area, invasive alien species, soil and water pollution, hunting/trapping, severe climate change, constructing dams for water management, human disturbance, transport/service corridors, intensive rice cultivation, and high use of pesticides and fertilizers in the wetland crop fields (Figure 3). References [20-22] report that loss of wetland habitats and land degradation are the consequences of overexploitation, alien invasive species, climate change, and pollution. Since early decades, these types of issues have been increasing severely in the wetland 


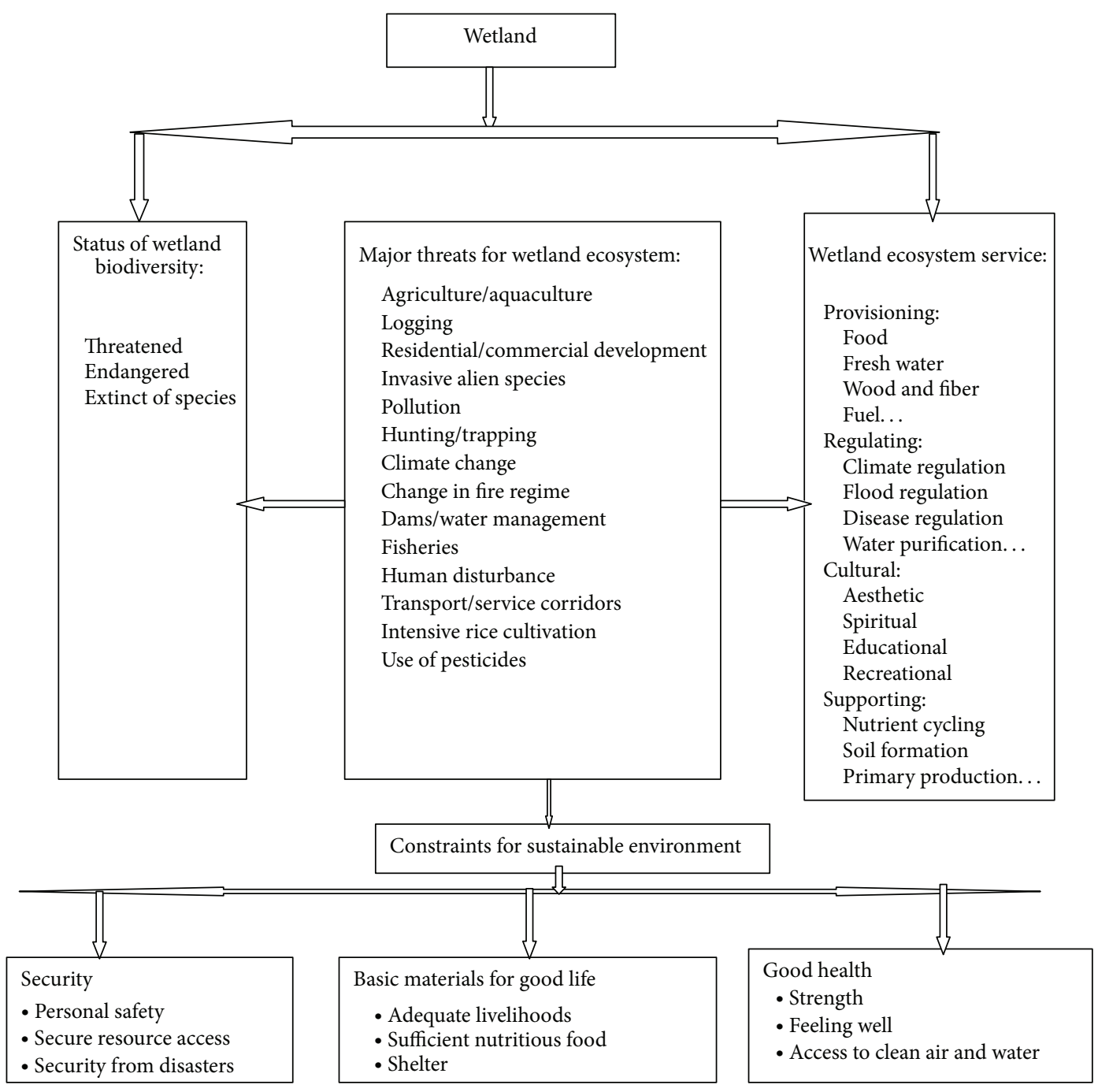

FIgURE 3: Threats on wetlands biodiversity and ecosystem service.

ecosystem area [23]. As a result, among the recorded species, the total percentage of visible, threatened, endangered, and extinct species was $69.23,18.62,10$, and $1.92 \%$ in the wetland ecosystems of Mohangonj, respectively. This is similar to how some species have disappeared in other parts of the world such as polar bears, sea turtles, pika, golden frogs, and harlequin frogs [24-27] and one million species are in an extinction category in the world [28].

Wetland connectivity protects natural ecosystems. This connectivity is important for species richness in wetland ecosystem because of the development of suitable habitats for species conservation [29]. But the sustainable agricultural system has focused on the expansion of agricultural farming which is the global principal driver to the loss of wetland connectivity and natural resources [30-32]. As a consequence, people in the wetland have been producing agricultural crops intensively. Different pests' biotypes have increased in the crop fields due to different cropping patterns and climate change. They have been applying pesticides in their crop fields for the protection of pests. This type of agricultural activity is important for crop cultivation, but it is the key threat in the wetland ecosystem resiliency [33-35]. Similarly, consistence land use changes impact wetland biodiversity. For example, two-thirds of 333 farmland species (broadleaved plants, butterflies, bumblebees, birds, and mammals) are threatened by agricultural intensification at the end of the 20th Century [36]. In the same way, some of the species are threatened, endangered, and extinct in the study areas of wetland ecosystem due to intensive sustainable agricultural practices.

Moreover, industrial pollution is the driver of wetland biodiversity depletion [37]. Different types of industries have increased in Bangladesh due to the economic growth and foreign investment. As a result, people do not protect the natural resources in the wetland ecosystem because they earn more money from industry rather than the protection of natural resources in the wetlands. Even though wetland is one of the greatest biological resources for the protection of sustainable environment, it is disrupted due to the inconsideration of natural resources. Reference [38] 


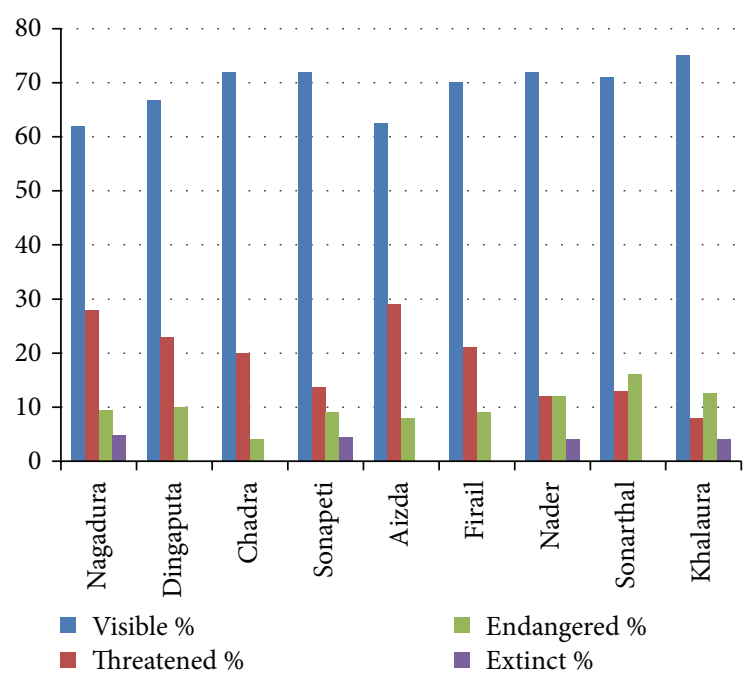

FIGURE 4: Graphical presentation of visible, threatened, endangered, and extinct species of different wetland ecosystem at Mohangonj upzila in Netrokona.

reports that birds and fish are important bioindicators for maintaining the aquatic vegetation in the wetland ecosystem, but these bioindicators are in decline due to the industrial pollution, habitat alteration, introduction of alien species, and commercial exploitation in the wetland ecosystem [39]. Similarly, the wetland species are threatened, endangered, and extinct in this wetland ecosystem due to these kinds of major environmental threats (Table 2 and Figure 3).

Since 1970 , a total of $3 \%$ terrestrial, $14 \%$ marine, and $35 \%$ freshwater populations have disappeared due to the anthropogenic activities in the world $[40,41]$. Sixty percent of the 1,146 freshwater taxa are assessed as threatened, and 228 species are extinct since the last century because of water pollution in the wetland ecosystem [42]. In this circumstance, wetland biodiversity has been continuously threatened all over the world [23]; nine million different types of plants, animals, and fungi inhabit are dismantled in the earth's ecosystems [43]. These kinds of problems are elevated in the wetland ecosystems because of major environmental threats. These threats also impact wetland ecosystem services such as food, fuel, water, climate regulation, aesthetic, spiritual, recreational activities, and soil nutrient cycling. As a result, some constraints are already established in the wetland areas such as a lack of personal security, basic materials, and good health which leads to deteriorating the sustainable environment for the species conservation.

The wetland ecosystem is significantly important for species conservation, ecosystem service, and sustainable livelihood. This wetland ecosystem is also necessary for carbon sequestration from the atmosphere because of their varied species composition, tree density, and leaf litter deposition. For instance, a high percent of soil carbon is stocked at Himachal Pradesh forest area in India due to the wellprotected forest and its higher biomass which sequesters significantly more carbon compared to other forest ecosystems [44]. As a consequence, wetland biodiversity can reduce global warming and is a local mitigation measure for climate change.

The protection of wetland biodiversity is necessary for the mitigation of climate change. It can be protected in different ways by maintaining the wetlands connectivity, using recommended doses of pesticides and fertilizers in the surrounding crops fields, planning well urbanization, stopping deforestation, avoiding artificial fish culture in the wetlands, managing of the aquatic vegetation properly, avoiding hunting of the migratory birds and other animals, avoiding continuous fishing, monitoring of the species status continuously, harvesting of rainwater, maintaining water flow, increasing the public awareness, inspiring the people who depend on wetland resources for alternative adoption, and implementing rules and regulations for the conservation of wetland resources by the government. Also, changes of the wetland biodiversity and ecosystem services might be maintained through the guidelines of [45] by adopting proactive attitude in support of a sustainable environment. It is expected that wetland biodiversity and ecosystem service will play a vital role at the science-policy interface as described by [46]. Therefore, continuous research and monitoring on wetland biodiversity and ecosystem services are essential for the protection of sustainable environments and climate change in the world.

\section{Conclusion}

The status of wetland biodiversity is at an extreme risk due to major environemntal threats. Wetland species are threatened and endangered; some of the species have totally disappeared in the wetland ecosystem. Among the recorded species, the total percentage of visible, threatened, endangered, and extinct species was $69.23,18.62,10$, and $1.92 \%$ in these wetland ecosystems, respectively. As a consequence, wetland ecosystem protection is important for species conservation and the protection of a sustainable environment.

\section{Conflict of Interests}

The author declares that there is no conflict of interests regarding the publication of this paper.

\section{Acknowledgment}

The author is immensely grateful to the Bangabandhu Sheikh Mujibur Rahman Agricultural University, Gazipur, Bangladesh, for funding these research activities.

\section{References}

[1] The Ramsar Convention, 2009, http://www.ramsar.org/cda/en/ ramsar-about-faqs-what-are-wetlands/main/ramsar/1-36-37\% 5E7713_4000_0_.

[2] Chapman \& Hall, Global Biodiversity: Status of the Earth's Living Resources, World Conservation Monitoring Center, London, UK, 1992.

[3] UNEP, Global Environment Outlook 3, 2003. 
[4] P. Comer, A. K. Goodin, G. Tomaino et al., Biodiversity Values of Geographically Isolated Wetlands in the United States, Nature Serve, Arlington, Va, USA, 2005.

[5] Florida Fish and Wildlife Commission (FWC), Florida's Wildlife Legacy Initiative, Tallahassee, Fla, USA, 2011, http:// myfwc.com/conservation/specialinitiatives.

[6] Coastal Wetland Biodiversity Managgement Plan (CWBMP), "Hakaluki Haor Management Plan," UNDP, 2005.

[7] M. A. Sattar and M. Z. Alam, "Study of biodiversity at some wetland areas of Bhaluka," Bangladesh Journal of Environmental Science, vol. 10, no. 1, pp. 216-219, 2004.

[8] M. Z. Alam, "Study of threatened, rare-endangered and extinct fish species at some wetland areas of Bhaluka region of Mymensingh," Bangladesh Journal of Environmental Science, vol. 11, no. 2, pp. 450-453, 2005.

[9] CBD, Global Biodiversity Outlook 3, Secretariat of the Convention on Biological Diversity, Montreal, Canada, 2010.

[10] TEEB, The Economics of Ecosystems and Biodiversity: Mainstreaming the Economics of Nature: A Synthesis of the Approach, Conclusions and Recommendations of TEEB, The Economics of Ecosystems and Biodiversity, Progress Press, Valletta, Malta, 2010.

[11] W. J. Sutherland, W. M. Adams, R. B. Aronson et al., "One hundred questions of importance to the conservation of global biological diversity," Conservation Biology, vol. 23, no. 3, pp. 557-567, 2009.

[12] M. S. Hossain, G. D. Nani, and M. S. N. Chowdhury, Fisheries Management of Naaf River, Institute of Marine Science and Fisheries, University of Chittagong,, University of Chittagong and Center for Good Governance, Chittagong, Bangladesh, 2007.

[13] J. S. Larson, P. R. Adamus, and J. E. J. Clairain, Functional Assessment of Freshwater Wetlands: A Manual and Training Outline, WWF Publication, Glaud, Switzerland, 1989.

[14] E. B. Barbier, M. Acreman, and D. Knowler, Economic Valuation of Wetlands: A Guide for Policy Makers and Planners, Ramsar Convention Bureau, Gland, Switzerland, 1997.

[15] R. T. Woodward and Y.-S. Wui, "The economic value of wetland services: a meta-analysis," Ecological Economics, vol. 37, no. 2, pp. 257-270, 2001.

[16] C. M. Cheffings and L. Farrell, The vascular plant red data list for Great Britain No. 7. JNCC, Peterborough, UK, 2005.

[17] E. B. Barbier, "An approach to economic evaluation of tropical wetlands: with examples from Guatemala and Nicaragua," in Caribbean Ecology and Economics, Caribbean Conservation Association, N. P. Girvan and and D. Simons, Eds., pp. 207-231, St. Michael, Bridgetown, Barbados, 1991.

[18] T. Keeler, D. R. Elan, K. Lewis, and S. A. Flint, "California vernal pool assessment," Preliminary Report, State of California, Deptpartment of Fish and Game, Sacramento, Calif, USA, 1998.

[19] J. M. Jankovski, C. M. C. Coulter, and B. Mosley, Riparian and Wetland Plant Associations of Southwestern Idaho, with Focus on the Bureau of Land Management's Lower Snake River District, Idaho Department of Fish and Game and Idaho Conservation Data Center, 2001.

[20] J. E. M. Baillie, J. Griffiths, S. T. Turvey, J. Loh, and B. Collen, Evolution Lost: Status and Trends of the Worlds Vertebrates, Zoological Society of London, London, UK, 2010.

[21] J. C. Vie, C. Hilton-Taylor, and S. N. Stuart, Eds., Wildlife in a Changing World. An Analysis of the 2008 IUCN Red List of Threatened Species, International Union for Conservation of Nature, Gland, Switzerland, 2009.
[22] Millennium Ecosystem Assessment, Ecosystems and Human Well-Being: Synthesis. Millennium Ecosystem Assessment, World Resources Institute. Island Press, Washington, DC, USA, 2005.

[23] S. H. M. Butchart, M. Walpole, B. Collen et al., "Global biodiversity: Indicators of recent declines," Science, vol. 328, no. 5982, pp. 1164-1168, 2010.

[24] G. M. Durner, J. P. Whiteman, H. J. Harlow, S. C. Amstrup, E. V. Regehr, and M. Ben-David, "Consequences of long-distance swimming and travel over deep-water pack ice for a female polar bear during a year of extreme sea ice retreat," Polar Biology, vol. 34, no. 7, pp. 975-984, 2011.

[25] E. S. Poloczanska, C. J. Limpus, and G. C. Hays, "Vulnerability of marine turtle to climate change," in Advances in Marine Biology, D. W. Sims, Ed., vol. 56, pp. 151-211, Elsevier Academic Press, San Diego, Calif, USA, 2009.

[26] J. A. Pounds, M. R. Bustamante, L. A. Coloma et al., "Widespread amphibian extinctions from epidemic disease driven by global warming," Nature, vol. 439, no. 7073, pp. 161$167,2006$.

[27] E. A. Beever, C. Ray, J. L. Wilkening, P. F. Brussard, and P. W. Mote, "Contemporary climate change alters the pace and drivers of extinction," Global Change Biology, vol. 17, no. 6, pp. 2054-2070, 2011.

[28] C. D. Thomas, A. Cameron, R. E. Green et al., "Extinction risk from climate change," Nature, vol. 427, no. 6970, pp. 145-148, 2004.

[29] N. Ishiyama, T. Akasaka, and F. Nakamura, "Mobility dependent response of aquatic animal species richness to a wetland network in an agricultural landscape," Aquatic Sciences, vol. 76, p. 2, 2014.

[30] L. Brussaard, P. Caron, B. Campbell et al., "Reconciling biodiversity conservation and food security: scientific challenges for a new agriculture," Current Opinion in Environmental Sustainability, vol. 2, no. 1-2, pp. 34-42, 2010.

[31] IAASTD, "Agriculture at a crossroads. Synthesis report," in International Assessment of Agricultural Knowledge, Science and Technology for Development, B. D. McIntyre, H. R. Herren, J. Wakhungu, and R. T. Watson, Eds., Island Press, Washington, DC, USA, 2009.

[32] Millennium Assessment, Ecosystems and Human Well-Being: Wetlands and Water Synthesis. Millennium Ecosystem Assessment, World Resources Institute. Island Press, Washington, DC, USA, 2005.

[33] M. H. Benson and A. S. Garmestani, "Can we manage for resilience? The integration of resilience thinking into natural resource management in the United States," Environmental Management, vol. 48, no. 3, pp. 392-399, 2011.

[34] A. S. Mori, "Ecosystem management based on natural disturbances: hierarchical context and non-equilibrium paradigm," Journal of Applied Ecology, vol. 48, no. 2, pp. 280-292, 2011.

[35] C. A. Johnston, "Cumulative impacts to wetlands," Wetlands, vol. 14, no. 1, pp. 49-55, 1994.

[36] S. J. Butler, D. Brooks, R. E. Feber, J. Storkey, J. A. Vickery, and K. Norris, "A cross-taxonomic index for quantifying the health of farmland biodiversity," Journal of Applied Ecology, vol. 46, no. 6, pp. 1154-1162, 2009.

[37] B. J. Coppins, S. Street, and L. Street, "Lichens of Aspen Woods in Strathspey. Unpublished Report," 2001, http://www.treesforlife.org.uk/tfl.aspen_lichen_ecology.html.

[38] J. Palacio-Núñez, J. R. Verdú, E. Galante, D. Jiménez-García, and G. Olmos-Oropeza, "Birds and fish as bioindicators of 
tourist disturbance in springs in semi-arid regions in Mexico: a basis for management," Animal Biodiversity and Conservation, vol. 30, no. 1, pp. 29-41, 2007.

[39] B. M. Peter and A. L. Robert, "Conservation biology," in Loss of Biodiversity in Aquatic Ecosystems: Evidence from Fish Faunas, pp. 127-169, Springer, 1992.

[40] K. D. Boylan and D. R. MacLean, "Linking species loss within wetlands," National Wetlands Newsletter, vol. 19, pp. 13-17, 1997.

[41] D. S. Wilcove, M. McMillan, and K. C. Winston, "What exactly is an endangered species? An analysis of the U.S. endangered species list: 1985-1991," Conservation Biology, vol. 7, pp. 19851991, 1993.

[42] M. Dumortier, L. de Bruyn, and M. Hens, Biodiversity Indicators 2007. State of Nature in Flanders (Belgium), Research Institute for Nature and Forest Brussels, 2007.

[43] B. J. Cardinale, J. E. Duffy, A. Gonzalez et al., "Biodiversity loss and its impact on humanity," Nature, vol. 486, pp. 59-67, 2012.

[44] R. Ray, M. D. S. Chandran, and T. V. Ramachandra, "Biodiversity and ecological assessments of Indian sacred groves," Journal of Forestry Research, vol. 25, no. 1, pp. 21-28, 2014.

[45] P. Peduzzi, R. Harding, J. Richard, S. Kluser, L. Duquesnoy, and B. Boudol, UNEP Foresight Process: Phase I: Results of the UNEP Consultation, United Nations Environment Program, Nairobi, 2011.

[46] C. Perrings, A. Duraiappah, A. Larigauderie, and H. Mooney, "The biodiversity and ecosystem services science-policy interface," Science, vol. 331, no. 6021, pp. 1139-1140, 2011. 

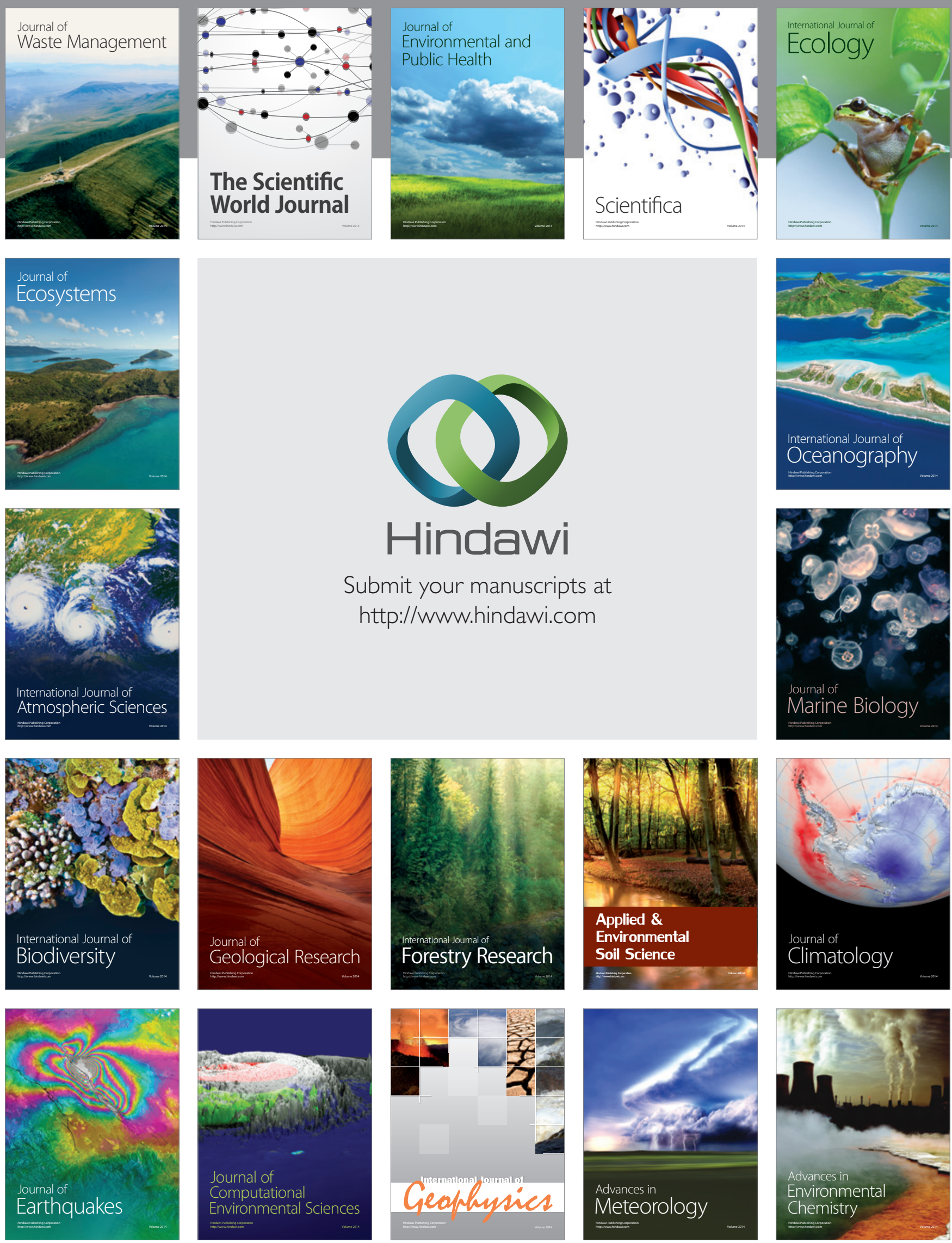